\title{
鉄道車両に搭載された衛星追尾アンテナのプログラム追尾の 実現性に関する検討*1 \\ A Feasibility Study on the Program Tracking of the Satellite Tracking Antenna Mounted on Train
}

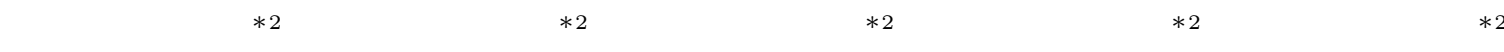 \\ Hironori Ishikawa, Jin Mitsugi, Fumiaki Nagase, Masazumi Ueba and Mitsunobu Watanabe
}

Key Words : Satellite Communication, Satellite Tracking Antenna, Program Tracking

\begin{abstract}
We have proposed mobile multimedia satellite communication system designed to realize high-speed multimedia communications. This system uses a mobile network for the return link and the developed satellite-tracking antenna that receives high-speed satellite signals for the forward link. The satellite-tracking antenna, which consists of four planar antennas, measures the pointing error by the phase monopulse and has achieved the satellite-tracking control by the co-phasing combining and the mechanical drive. When the satellite-tracking antenna is applied to the car and the ship, it is necessary to decide the tracking drive angle constantly. When it is applied to the train, the satellite-tracking can be expected to be achieved by specifying the tracking drive angle in accordance with the distance because the train runs in the same route. This tracking method is called a program tracking in this paper. This paper describes the tracking drive angle and the error factor of the program tracking quantitatively. We concluded that it was possible to apply the program tracking to the train if operating rate of the system was $70 \%$ or less.
\end{abstract}

\section{1. は じめに}

近年 , ADSL , 無線アクセスなどブロードバンドインター ネットの利用が急激に増加している．今後は移動中におい てもマルチメディアコンテンツにアクセスしたいという要 望が高まり，低コストで高速通信が可能なサービスが必要 になってくる．この要求を満たすために，自動車をはじめ とした樣々な移動体において高速インターネットアクセス を提供するための研究開発が活発に行われている1 3).

インターネットにおける回線速度は, サーバからクライ アントへの下り回線は高速であることを必要とするが, ク ライアントからサーバへの上り回線は低速でもよいという 特徵がある4). 弚こで, 著者らは移動中でも高速なマルチ メディア通信を実現するために, 移動体からの上り回線と して携帯電話に代表される地上移動通信網を利用し，下り 回線として衛星追尾アンテナを使用した高速な衛星回線を 利用するモバイルマルチメディア衛星通信システムを提案， 構築してきた5 7). 本システムのサービスイメージを第 1 図に示す . 移動体からの要求信号などは移動通信網により サーバへ送信される．サーバから提供される動画などの大 容量マルチメディアコンテンツは衛星回線を経由して最大 約 $30 \mathrm{Mbit} / \mathrm{s}$ の伝送速度で各移動体へ配信される . モバイ

\footnotetext{
*1 (C) 2004 日本航空宇宙学会

平成 15 年 8 月 7 日原稿受理

*2 日本電信電話 (株) NTT 未来ねつと研究所
}

ルマルチメディア衛星通信システムの有効性を実証するた めに, 現在までに衛星追尾アンテナを自動車 ${ }^{8)}$, 鉄道車両 ${ }^{9)}$ および船舶に搭載した場合の実験的評価を行い, 移動中で もポインティング損失が $1 \mathrm{~dB}$ 以下の追尾精度を確保でき ることを確認している．

衛星追尾アンテナを自動車や船舶, 航空機に適用する場 合には, 移動のたびに衛星追尾角度を決める要因 (例えば 道程や航程, 道路状況や海面状況) が異なるため, あらか じめ衛星追尾角度を指定することはできないが, 鉄道車両 の場合には一旦路線が決まってしまえば衛星追尾角度を線 路上の位置に応じて指定することで衛星追尾が実現できる ことが期待できる．本稿ではこれをプログラム追尾と呼ぶ ことにする . プログラム追尾が可能になれば, 衛星追尾ア ンテナの駆動角度範囲や追尾角速度といった要求性能の低 減や炎れによる製造費の削減, またトンネルなどの遮蔽に より衛星追尾が不可能な区間を通過後の衛星捕捉時間が短 縮され, 稼働率 (全走行区間に対して衛星信号を受信でき る区間の割合) の向上などの利点がある .

プログラム追尾はこれまでにも言及されている ${ }^{10)}$ が , 実 現性について定量的に検討した例は報告されていない，光 こで本稿ではプログラム追尾の実現方法および, 弚れを適 用する場合に追尾精度決定のために必須である衛星追尾角 度の誤差評価方法を提案するとともに, 害際の鉄道車両走 行データから衛星追尾角度誤差を定量的に評価し, プログ ラム追尾の実現性を定量的に検討した結果を報告する． 


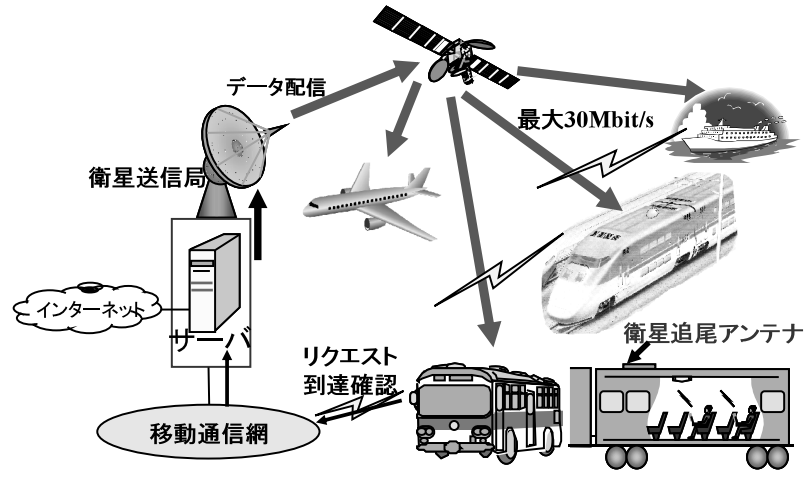

第1図 サービスイメージ

\section{2. プログラム追尾}

鉄道車両のように走行経路が一定である移動体において， 走行中にステップトラックやモノパルス等で衛星を追尾す るのではなく, 事前に取得した移動体の位置と衛星追尾角 度の関係に基づき，オープンループで衛星を追尾する方法 をプログラム追尾と本稿では定義する．本章ではまずプロ グラム追尾の実現方法を定め，このプログラム追尾を鉄道 車両に適用する場合に問題となる衛星追尾角度誤差の評価 方法を示す。

2.1 プログラム追尾の実現方法 プログラム追尾を実現 するためには, ある位置を起点にした軌道上の距離（キロ 程) に応じた衛星追尾角度を求めることが必要である。キ 口程は一般的に鉄道の運行システムにおいては車軸の回転 を測定することによって取得されている．このキロ程デー タに基づき, 衛星追尾アンテナに対して方位角，仰角方向 の衛星追尾角度指示値を制御器から送出することでオープ ンループ制御が可能である. 衛星追尾角度指示値はキロ程 に応じた緯度, 経度, 高度情報を地图データ等から読み取 り，衛星の追尾方向を決める方法も考えられるが，この手 法では鉄道軌道に必ず存在する線路の傾きを考慮すること ができず，衛星追尾角度誤差を生じる原因となる . ジャイ 口等により傾きデータを別途取得しこの軌道の傾きを補正 することも可能だが，指示値データの準備手順が複雑にな ると予想される．著者らか開発した衛星追尾アンテナ8) で は，位相モノパルス制御により方位角方向，仰角方向の駆 動角度を求めることができるため, 一旦このアンテナを搭 載して走行することで, キロ程に対応した衛星追尾角度指 示値を取得し，実際の運用では位相モノパルス制御機能を 有しない (つまり低コストの) 衛星追尾アンテナを取得し た衛星追尾角度指示值によってオープンループ制御するこ とか現実的である. 以下の検討ではこのようにして衛星追 尾角度指示值を取得することを想定する。

2.2 プログラム追尾時の衛星追尾角度誤差評価法 プ ログラム追尾を適用する場合に衛星追尾角度精度を決定す る誤差要因を抽出し，各要因に対する誤差量を評価する手 法を提案する.

2.2.1 プログラム追尾時の衛星追尾角度の誤差要因 衛 星追尾角度精度を決定する誤差要因として以下の 3 つを考
えた。

(1) キロ程の誤差 : キロ程は多くの場合，車軸の回転数に より求められるため車輪がレールに対してすべることに より誤差が生じる．衛星追尾角度指示値はキロ程に対し て設定されているため誤差が生じる．ただし鉄道によっ てはキロ程の校正を定期的に行っている場合もある.

(2) 車両傾き角度（ヨー軸回転，ロール軸回転，ピツチ軸 回転) の再現性 : 計画速度で同一の路線を走行した際で も，速度誤差や運転手の技量によって車体の傾き角度は 走行ごとに変化する.これにより衛星追尾角度に誤差が 生じる。

(3) 衛星追尾アンテナの振動 : 衛星追尾アンテナは鉄道車 両の屋根上にボル卜等で固定されることになる . 衛星追 尾アンテナの車輛への取り付け面と電波を受信するアン テナ面間の角度を衛星追尾角度指示值をもとに制御する わけだが，機械追尾を含む場合には機構を有するため取 り付け面とアンテナ面間での振動や熱変形によるアライ メント誤差が発生し，光れにより誤差が生じ，衛星追尾 角度指示値どおりに動かしたとしても誤差が生じる。 以下では上記の誤差要因を光れ光れ定量化する方法につい て述べる。

2.2.2 キロ程による誤差 キロ程による誤差 $(D i: i$ は回 転方向 (ヨー軸回転, ロール軸回転，ピッチ軸回転)を示す) を定量化するために同一区間の路線を複数回走行し，キロ 程を積算することにより駅間距離を求める. 実際にデータ を整理すると駅間距離は走行ごとに若干異なっており，こ れをキロ程の誤差と考えた . 車両傾き角度とキロ程の関係 において, 車両傾き角度を維持したままキ口程を誤差分増 加させた場合の軌跡を導く . 光して 2 つの車両傾き角度を 比較することで，キロ程による誤差を算出した．

2.2.3 車両傾き角度の再現性による誤差 車両傾き角度 の再現性による誤差 $(R i)$ を定量化するために, 同一の路線 を複数回走行し，キ口程に対する車両傾き角度を走行ごと に求める.上述したキロ程の誤差の影響を取り除くために， 駅ごとにキロ程を補正し，車両傾き角度を比較することで 車両傾き角度の再現性による誤差を算出した。

2.2.4 衛星追尾アンテナの振動による誤差 衛星追尾ア ンテナの振動による誤差 $(V i)$ を定量化するために，以下 の座標系を導入する．座標系は全て右手系で定義し，添え 字 $1,2,3$ で直交 3 軸を表す。

(1) 地表面系 $e:$ 走行地点における北方向に $e \_3$ 軸が , 西方 向に $e_{-} 1$ 軸，鉛直方向に $e_{-} 2$ 軸と定義する.

(2) 鉄道車両初期系 $\boldsymbol{r}_{\mathrm{O}}$ : 地表面座標系を $e_{-} 2$ 軸周りに回転 させ起点における鉄道車両の進行方向を $r_{\mathrm{o}-1} 1$ となるよう に定めた座標系 .この時点では鉄道車両の屋根や底面は 水平面上にあると仮定しており，起点における角度誤差 はあとで導入する。

(3) 鉄道車両走行系 $r:$ 鉄道車両初期系を $r_{\mathrm{o}} 2$ 軸周りに $\psi$ だけ回転してヨー軸回転，続いて $r_{\mathrm{o}} 3$ 軸周りに $\theta$ だけ ピッチ軸回転， $r_{\mathrm{o}} 1$ 軸周りに $\phi$ だけロール軸回転させた 座標系. 実績により $\theta$ と $\phi$ は線形化可能な程度に小さ 
いと考える

(4) 衛星追尾アンテナベースプレート系 $\boldsymbol{a}_{\mathrm{o}}: r$ 座標系を回転 させて衛星追尾アンテナのベースプレートに固定する系 . これは屋根上に取り付ける際のヨー軸, ロール軸, ピッ チ軸の取り付け誤差および後述する追尾アンテナ系のア ジマス $=0$ 方向によって決定される .

(5) 追尾アンテナ系 $\boldsymbol{a}$ : 追尾アンテナのアンテナ面に固定さ れた座標系であり，衛星方向が $a \_3 ，$ 仰角制御が $a \_1$ 軸 周り，方位角制御が $a \_2$ 軸周りとなるように決定した座 標系 .

上記で定義した座標系間の関係は回転変換行列を用いて 次のように表すことができる．ここで $\boldsymbol{e}, \boldsymbol{r}_{\mathrm{o}}$ 等は直交 3 軸 の単位ベクトルの方向を文献 11) に述べられる手法で記述 したものである .

$$
\begin{aligned}
& \boldsymbol{r}_{\mathrm{o}}=\boldsymbol{e} R_{\mathrm{yo}} \\
& \boldsymbol{r}=\boldsymbol{r}_{\mathrm{o}} R_{\mathrm{y}} R_{\mathrm{p}} R_{\mathrm{r}} \\
& \boldsymbol{a}_{\mathrm{o}}=\boldsymbol{r} R_{\mathrm{rao}} \\
& \boldsymbol{a}=\boldsymbol{a}_{\mathrm{o}} \Psi_{\mathrm{a}} \Phi_{\mathrm{a}}
\end{aligned}
$$

さて，(1)の $R_{\mathrm{yo}}$ は鉄道車両起点での鉄道車輌方向がわか れば求めることができる . (2) における $R_{\mathrm{y}}, R_{\mathrm{p}}, R_{\mathrm{r}}$ は鉄道 に加速度計, ジャイ口計を搭載することで求めることがで きる.(3)における $R_{\mathrm{rao}}$ はキ口程起点における緯度，経度， 高度が取得できれば, 求めることができる.つまり起点に おける追尾アンテナ系 $a$ と地表面系 $e$ の関係は起点の緯度， 経度, 高度情報と衛星の軌道上位置を用いて次の形で求め ることが可能である。

$$
a=e R_{\text {ea }}
$$

キロ程起点における鉄道の傾き情報と衛星追尾アンテナの 駆動角度情報を用い，式 (1) （4) と（5) を等值することで $R_{\text {rao }}$ は次の形で求めることができる .

$$
R_{\text {rao }}=R_{\mathrm{r}}^{\mathrm{T}} R_{\mathrm{p}}^{\mathrm{T}} R_{\mathrm{y}}^{\mathrm{T}} R_{\text {yo }}{ }^{\mathrm{T}} R_{\mathrm{ea}} \Psi_{\mathrm{a}}^{\mathrm{T}} \Phi_{\mathrm{a}}^{\mathrm{T}}
$$

これらの関係を用いれば，走行状態において測定した $R_{\mathrm{r}}, R_{\mathrm{p}}, R_{\mathrm{y}}, \Psi_{\mathrm{a}}, \Phi_{\mathrm{a}}$, (5) で求めた $R_{\mathrm{ea}}$ と (6) で求めた $R_{\text {rao }}$ を用いることで, 走行中の追尾アンテナと取り付けプレー 卜間の振動による誤差回転行列 $E$ は以下を満足することが わかる.

$$
R_{\text {yo }} R_{\mathrm{y}} R_{\mathrm{p}} R_{\mathrm{r}} R_{\mathrm{rao}} \Psi_{\mathrm{a}} \Phi_{\mathrm{a}} E=R_{\mathrm{ea}}
$$

ここで, $E$ はヨー軸回転，ロール軸回転，ピッチ軸回転の 誤差成分を微小回転角度 $\psi_{\mathrm{e}}, \phi_{\mathrm{e}}, \theta_{\mathrm{e}}$ として

$$
E=\left[\begin{array}{ccc}
1 & -\theta_{\mathrm{e}} & \psi_{\mathrm{e}} \\
\theta_{\mathrm{e}} & 1 & -\phi_{\mathrm{e}} \\
-\psi_{\mathrm{e}} & \phi_{\mathrm{e}} & 1
\end{array}\right]
$$

となる .

このように鉄道車両を走行させヨー軸回転，ロール軸回転， ピッチ軸回転を測定し，衛星追尾アンテナで方位角，仰角を 測定しておけば $E$ マトリクスを定量化することができる .
2.2.5 衛星追尾角度誤差 2.2.2 2.2.4 章で算出した誤 差 (キ口程による誤差 $D i$, 車両傾き角度の再現性による 誤差 $R i$ ，衛星追尾アンテナの振動による誤差 $V i$ ) は，性 質上独立しているためプログラム追尾による誤差の総和 $S i$ は次式により算出することができる .

$$
S i=\sqrt{D i^{2}+R i^{2}+V i^{2}}
$$

\section{3. 適用例}

代表的な鉄道路線において鉄道車両を走行させた実験を 行い, 衛星追尾角度誤差評価を定量的に評価した .まず, 鉄 道車両に衛星追尾アンテナを搭載して，マルチメディア衛 星システムに適用するための要求条件を示す．次に実際の 衛星追尾角度誤差を提案した評価式から算出する. 乥して 鉄道車両に対するプログラム追尾の実現性を検証する．

3.1 要求追尾精度 モバイルマルチメディア衛星通信シ ステムでは, 回線設計上許容されるポインティング損失を $1 \mathrm{~dB}$ としており ${ }^{8)}$ ，これに対して許容される指向方向誤差 を実測により求めた . 本追尾アンテナと衛星が正対してい る状態から方位角方向，および仰角方向にアンテナを動か し，弚のときに受信した衛星ビーコン波の受信レベルの変 化を測定した，方位角指向特性を第 2 図，仰角指向特性を 第 3 图に示す.第 2 図, 第 3 図から要求衛星追尾角度誤差 は方位角で $-1.8 \sim+2.4^{\circ}$ となり，小さいほうを要求精度と して 1.8 度 PP (Peak to Peak), 仰角も同樣に $-3 \sim+2^{\circ}$ であるので, 要求精度は 2 度 PP である. 簡単のために仰

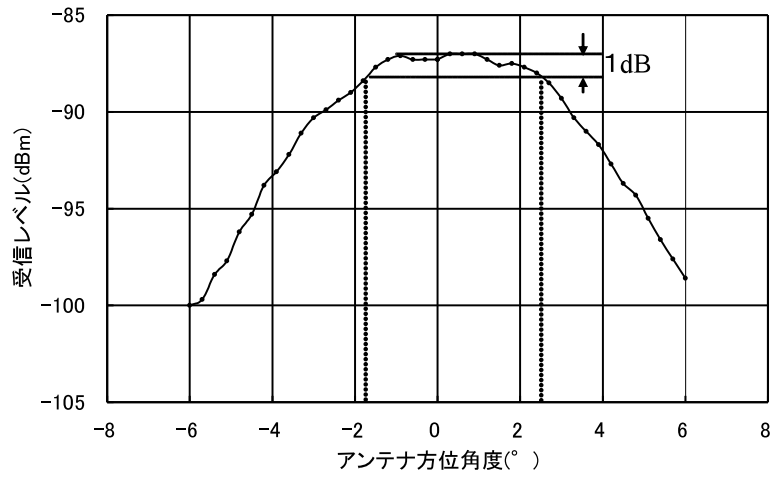

第2图 追尾アンテナの方位角指向特性

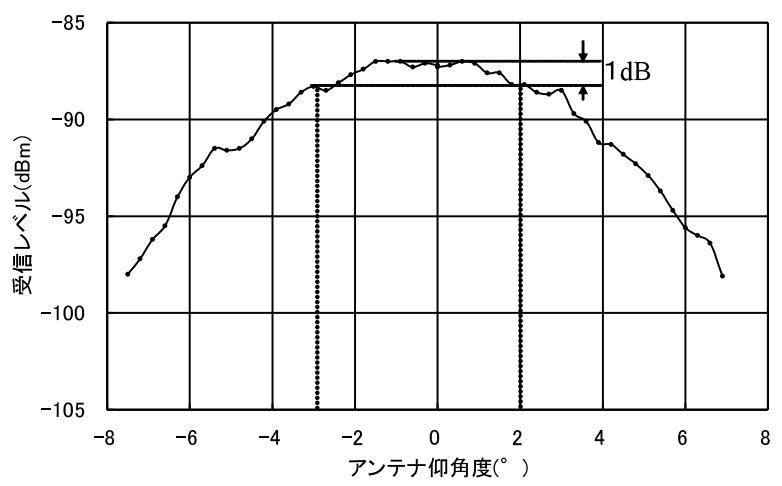

第3 図 追尾アンテナの仰角指向特性 
角，方位角ともに 1.8 度 PP を要求精度と考える。

3.2 衛星追尾角度の誤差評価

3.2.1 キロ程による誤差 キロ程の誤差を定量化するた めに, 同一区間の路線を往復し, 弚れ光れの速度から算出 したキロ程を比較した。弚の結果，キ口程の算出誤差平均 は約 $2 \%$ であることがわかった . キロ程に約 $2 \%$ の誤差を持 つ場合の車両傾き角度変化を検討した . まず実測した車両 傾き角度とキロ程の関係において, 車両傾き角度を維持し たままキロ程を $2 \%$ 増加させた場合の軌跡を導く. 次に $2 つ$ の軌跡の車両傾き角度の差を算出し, キロ程による誤差と した (第 4 図).キロ程による誤差の平均，および標準偏 差 $(\sigma)$ を第 1 表に示す.ヨ一軸回転およびロール軸回転 の誤差は 3.1 章で示した要求精度 1.8 度 PP を超えている ことがわかる．乥こで，キ口程を定期的に補正した場合の 車両傾き角度の誤差量を第 2 表に示す．第 2 表を参照する と, ロール軸回転, ピッチ軸回転の平均値以外は, キ口程 補正区間が減少すると誤差量が減少していることがわかる ロール軸回転，ピッチ軸回転の平均値において，有効析数 を $10^{-2}$ に設定したため，0.01の違いが生じているが，実 際の誤差量は最大 0.003 と非常に小さい. また，各軸回転 の誤差量は誤差の平均に誤差の標準偏差 $(\sigma)$ を加えた值 であり, 各軸回転の誤差量はキロ程補正区間が減少するこ とにより減少している。よって，定期的にキ口程の補正を 行うことで，キ口程による誤差を大幅に小さくすることが 可能である.

3.2 .2 車両傾き角度の再現性による誤差 再現性による 誤差を定量化するために，走行日の異なる試験結果におい て, 車両傾き角度を比較した .上述したように算出したキ

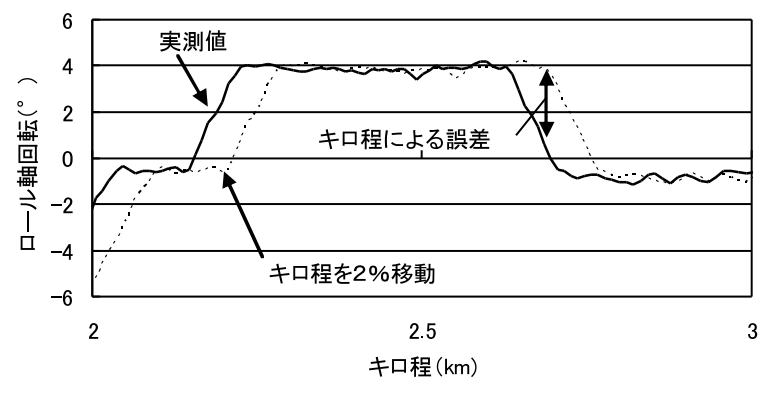

第 4 図 キロ程による誤差

第 1 表 キロ程による誤差量

\begin{tabular}{lrc}
\hline & 平均 $\left({ }^{\circ}\right)$ & 標準偏差 $\left(^{\circ}\right)$ \\
\hline ヨー軸回転 & -0.60 & 19.22 \\
ロール軸回転 & 0.06 & 3.26 \\
ピッチ軸回転 & 0.01 & 0.51 \\
\hline
\end{tabular}

口程は約 $2 \%$ の誤差を持つことから，2.2.3 章に述べた手法 によってキロ程誤差を補正した，弚の後，車両傾き角度を 比較し，再現性による誤差を算出した (第 5 図). 第 5 図 において, case 1 , case 2 は走行日の異なる同路線の試験 結果であり, case 2 はキロ程データを駅ごとで補正するこ とにより車両が傾く位置を case 1 と一致させている .

3.2.3 衛星追尾アンテナの振動による誤差 2.2 .4 章に述 ベた方法を用いてロール軸周りの衛星追尾アンテナの振動 による誤差を第 6 図に示す . キロ程が $1 \mathrm{~km}$ から $2 \mathrm{~km}$ の間 で大きな誤差が出ているが，これは遮蔽物によって衛星追 尾アンテナから衛星が見えなくなり，正確な方位角，仰角 が与えられなかったことが原因である .この区間を除き衛 星追尾アンテナの振動による誤差を算出した . 乥れ光れの 誤差の平均, および標準偏差 $(\sigma)$ を第 3 表に示す .ピッチ 軸回転に比べてロール軸回転，ヨー軸回転の誤差が小さい のは, 振動誤差は 3 軸で生じるにもかかわらず実際の制御

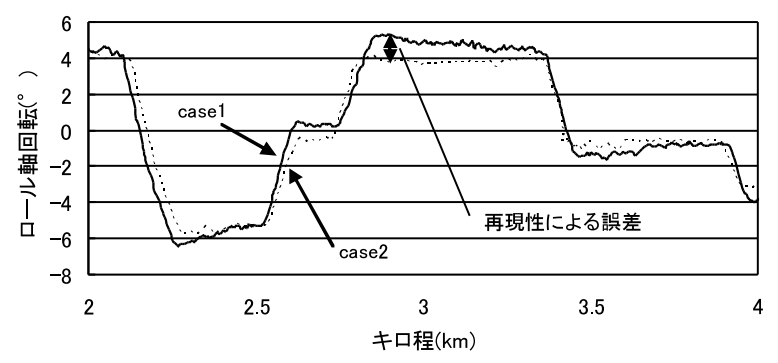

第 5 図 車両傾き角度の再現性による誤差

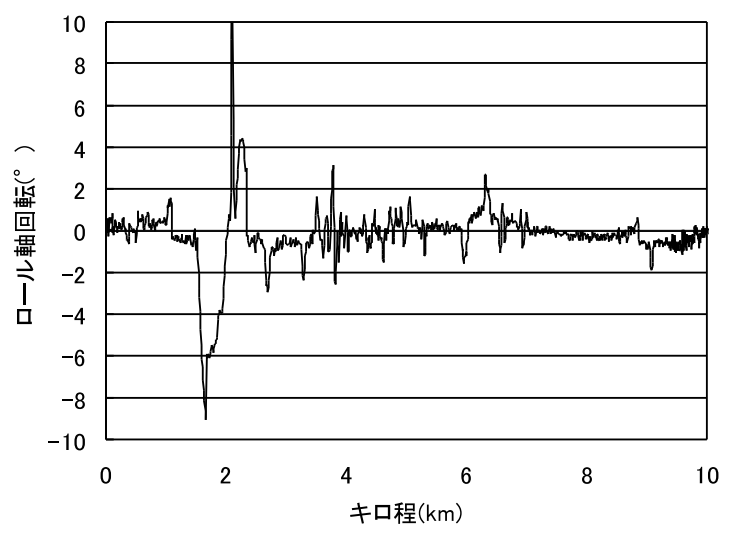

第 6 図＼cjkstart衛星追尾アンテナの振動による誤差

第 3 表 衛星追尾アンテナの振動による誤差量

\begin{tabular}{lrc}
\hline & 平均 $\left({ }^{\circ}\right)$ & 標準偏差 $\left(^{\circ}\right)$ \\
\hline ヨー軸回転 & 0.01 & 0.22 \\
ロール軸回転 & -0.01 & 0.55 \\
ピッチ軸回転 & 0.66 & 1.09 \\
\hline
\end{tabular}

第 2 表 キロ程補正による誤差量の変化

\begin{tabular}{|c|c|c|c|c|c|c|}
\hline \multirow{2}{*}{$\begin{array}{l}\text { キロ程補正 } \\
\text { 区間 }(\mathrm{km})\end{array}$} & \multicolumn{2}{|c|}{ ヨ一軸回転 } & \multicolumn{2}{|c|}{ ロール軸回転 } & \multicolumn{2}{|c|}{ ピッチ軸回転 } \\
\hline & 平均 $\left({ }^{\circ}\right)$ & 標準偏差 $\left(^{\circ}\right)$ & 平均 $\left({ }^{\circ}\right)$ & 標準偏差 $\left(^{\circ}\right)$ & 平均 $\left({ }^{\circ}\right)$ & 標準偏差 $\left({ }^{\circ}\right)$ \\
\hline 0.5 & 0.00 & 0.69 & 0.01 & 0.31 & 0.02 & 0.13 \\
\hline 1 & 0.00 & 1.37 & 0.00 & 0.56 & 0.02 & 0.14 \\
\hline 2 & 0.00 & 2.70 & 0.00 & 1.01 & 0.01 & 0.17 \\
\hline 3 & 0.01 & 4.00 & 0.00 & 1.41 & 0.01 & 0.21 \\
\hline
\end{tabular}


第 4 表 プログラム追尾による衛星追尾角度誤差

\begin{tabular}{|c|c|c|c|c|c|c|}
\hline \multirow{2}{*}{ 誤差要因 } & \multicolumn{2}{|c|}{ ヨ一軸回転 } & \multicolumn{2}{|c|}{ ロール軸回転 } & \multicolumn{2}{|c|}{ ピッチ軸回転 } \\
\hline & 平均 $\left({ }^{\circ}\right)$ & 標準偏差 $\left(^{\circ}\right)$ & 平均 $\left({ }^{\circ}\right)$ & 標準偏差 $\left(^{\circ}\right)$ & 平均 $\left(^{\circ}\right)$ & 標準偏差 $\left({ }^{\circ}\right)$ \\
\hline キロ程 & & & & & & \\
\hline 補正 $(0.5 \mathrm{~km})$ & 0.00 & 0.69 & 0.01 & 0.31 & 0.02 & 0.13 \\
\hline 補正 (1 km) & 0.00 & 1.37 & 0.00 & 0.56 & 0.02 & 0.14 \\
\hline 補正 (2 km) & 0.00 & 2.70 & 0.00 & 1.01 & 0.01 & 0.17 \\
\hline 補正 (3 km) & 0.01 & 4.00 & 0.00 & 1.41 & 0.01 & 0.21 \\
\hline 再現性 & 0.00 & 1.89 & -0.03 & 0.71 & 0.04 & 0.38 \\
\hline 振動 & 0.01 & 0.22 & -0.01 & 0.55 & -0.01 & 0.55 \\
\hline
\end{tabular}

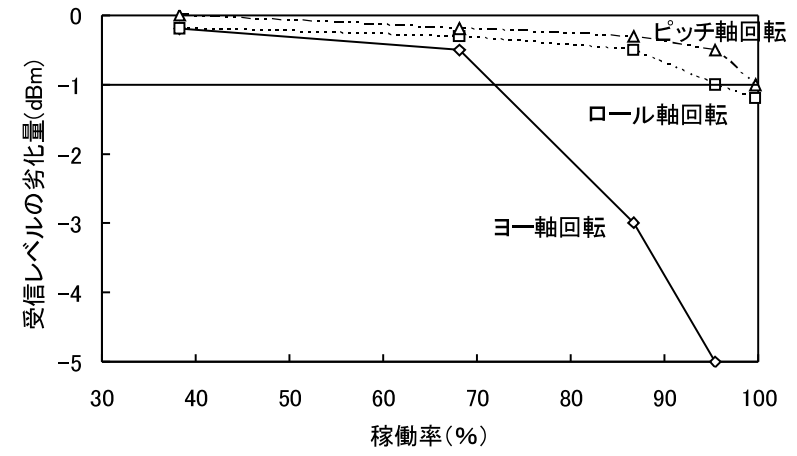

第 7 図＼cjkstart稼働率と受信レベルの劣化量の関係

軸が方位角と仰角の 2 軸であることが原因である．今回の 座標定義では仰角制御はロール軸回転に一致し，振動誤差 を衛星追尾で補っているため, ロール軸回転誤差は小さく なっていると考えられる .

3.3 プログラム追尾の実現性 プログラム追尾の誤差 要因をまとめて記述すると第 4 表になる . 3.2.3 章で算出 したピッチ軸回転は制御軸による補正を行っていないため， 正確な值ではない，光こで, 第 4 表において衛星アンテナ の振動による誤差のピッチ軸回転はロール軸回転と同一の 值を使用した . 第 4 表を参照すると，衛星追尾角度誤差は， キロ程補正区間を $0.5 \mathrm{~km}$ にした場合 (9) 式からヨー軸回転 で $2.0^{\circ}$ ，ロール軸回転で $1.0^{\circ}$ ，ピッチ軸回転で $0.7^{\circ}$ とな る.ここで，(9) 式に代入した各誤差は誤差の平均に誤差 の標準偏差 $(\sigma)$ を加えた值である. 次に, 各誤差の度数 分布はほぼ正規分布と見なせることから，各誤差の標準偏 差 $(\sigma)$ を $1 \sim 3 \sigma$ まで変化させ , 稼働率と受信レベルの劣 化量の関係を明らかにした結果を第 7 図に示す. 第 7 図を 参照すると，方位角に関しては稼働率 $70 \%$ 以下，仰角に関 しては稼働率 $95 \%$ 以下であれば, 要求条件である利得劣化 $1 \mathrm{~dB}$ 末満を満たすことができる.

以上のことから, 要求条件において, 衛星追尾角度誤差 のマージンが大きい，あるいは高稼働率を必要としないシ ステムにプログラム追尾を使用することは有効であると考 えられる . 追尾誤差マージンを大きくすることができない システムや稼働率を $95 \%$ 上大きくする必要があるシステ ムはプログラム追尾のみでは困難であり, 衛星追尾角度を 走行ごとに決定するシステムが必要である .

\section{4. 結論}

著者らは, モバイルマルチメディア衛星通信システムの
鉄道車両への適用において, 衛星追尾角度を線路上の位置 に応じて指定することで衛星追尾が実現できること(プロ グラム追尾) に着目した．乥して，プログラム追尾の実現 方法, 衛星追尾角度の誤差評価方法を提案し, プログラム 追尾の実現性を実際の鉄道車両走行データから定量的に検 討した . キ口程の誤差, 車両傾き角度の再現性, 衛星追尾 アンテナの振動による誤差から算出した衛星追尾角度誤差 を評価することにより，方位角に関しては稼働率 70\%以下， 仰角に関しては稼働率 $95 \%$ 以下であれば，モバイルマルチ メディア衛星通信システムの要求条件である利得劣化 $1 \mathrm{~dB}$ 未満を満たすことができることを明確にした .

今後，高精度なジャイロを使用することや，GPS 信号を 使用してヨ一軸回転に補正を行うこと，衛星追尾アンテナ のベースプレートとアンテナ面の剛性を高くすることで方 位角の誤差を低減することが期待できる。

$$
\text { 参 考 文 献 }
$$

1) de la Chapella, M., Parkman, D. S., Martens, P. J., Mclain, C. J. and Jenkins, J. C.: Connection by Boeing-Broadband Satellite Services for Aircraft, AIAA-Paper-2001-98, ICSSC, 2001.

2) Johnson, G. W., Kawamoto, R. and Bauer, D.: An Intelligent Router for Improved Network Performance over Mobile Satellite Links, AIAA-Paper-2001-43, ICSSC, 2001.

3) Nishimura, T., Mori, T., Ishii, J., Mori, T., Miyatsu, K., Matsuzawa, K. and Tomita, T.: Bluetooth Launch Trial in Hikari Rail Star, IEE-Japan Tech. Meeting on Transportation \& Electric Railway, TER-02-67, 2002, pp. 11-14.

4) Nakayama, M., Araki, K., Kobayashi, M. and Nakashima, H.: A Satellite Communication System Using ATM Multiplex Scheme for Interactive Multimedia Networks, 48th IAF, 1997.

5) 田中 博, 風間宏志, 中山正芳, 関 智宏, 永瀬文昭, 水野秀 樹: 高速移動体対応マルチメディア衛星通信システム, 信学技法, SANE99-126, SAT99-163 (2000-02), 2000, pp. 141-146.

6) 永瀬文昭,田中 博, 上羽正純: $\mathrm{Ku}$ バンド衛星回線を用いた移動 体での IP ネットワーク性能, 信学技法, SAT2001-55 (2001-10), 2001, pp. 77-82.

7) Nagase, F., Tanaka, H., Nakayama, M., Seki, T., Kazama, H. and Mizuno, H.: Mobile Multimedia Satellite Communication System at Ku Band, IEICE Trans. Commun., E84-B, 2001 .

8) Nagase, F., Tanaka, H., Mitsugi, J. and Ueba, M.: IP Network Performance of a Ku Band Mobile Multimedia Satellite System, 20th AIAA ICSSC, 2002.

9）石川博規, 三次 仁, 目黑 在, 永瀬文昭 : 鉄道車両に搭載され た衛星追尾アンテナの追尾精度に関する研究, 第 46 回宇宙科学 技術連合講演会講演集, 2002, pp. 1150-1155.

10) 関 清隆, 佐々木伸, 山村 博 : 列車における衛星放送受信の検 討, sat-87-1, 1987.

11) Kane, T. R., Linkins, P. W. and Levinson, D. A.: Spacecraft Dynamics, McGraw-Hill, 1983. 